\title{
Antígona E O DESEJO
}

\begin{abstract}
RESUMO
Este trabalho analisa, a partir dos estudos de gênero, a personagem de Antígona em relação ao desejo. Esta pesquisa está focalizada em três peças: Antígona furiosa, de Griselda Gambaro, Antígona, de Jean Anouilh, e Antígona, de Sófocles.
\end{abstract}

PALAVRAS - CHAVE

Antígona, desejo, morte

$\mathbf{E}_{\text {screver sobre as versōes que Sófocles (496 e } 406 \text { a. C.), Anouilh (1910-1986) }}$ e Griselda Gambaro (1928) realizaram submeteu-me a um período de leituras, análises e questionamentos. Lacan me levou à questăo do desejo e da morte, Kant ao conceito de liberdade, Hegel ao de dever, Lévi-Strauss ao de incesto e todos, incluindo os autores dos textos dramáticos, aos conceitos de Estado, Família, Cidade e Lei Divina.

Perguntei-me muitas vezes por que esta personagem me fascinava, como fascinou a tantos escritores, incluindo a Brecht, se isto somente dizia respeito à questão da afirmação genérica, ou se também produzia uma fascinação "perversa" por esse impulso de desejo incestuoso e morte que estrutura a personagem. Antígona nos deixa num espaço fálico, espaço onde o desejo feminino entra em contradição com a forma estabelecida desde o parâmetro de "racionalidade ocidental" e onde a morte foi a única saída que encontraram tantas heroínas literárias, como Ofélia de Shakespeare, citada na Antígona de Gambaro, e tantas mulheres de carne e osso, como as poetas Alfonsina Storni e Ana Cristina César.

Guyomard escreve:

Antígona fascina. Tem o brilho de sua beleza, terrível e trágica, que seduz, cativa e arrasta para um espaço mais além da vida. Ela se dirige para este e, ao mesmo tempo, mantém-se em seu limiar. Mais ainda, só guarda esse limiar, só marca sua linha e seu limite, ao preço de transpô-lo, sozinha à tumba em que será emparedada viva. ${ }^{\cdot}$

O que primeiro observei foi que a "racionalidade" de Creonte, gestora da morte de Antígona, ao ser desconstruída se revela como o mecanismo político que permite reprimir ou "persuadir" e que a "rebeldia irracional" de Antígona, questionada de imprudente em Sófocles, constitui-se numa forma simbólica de resistência heróica. Em Anouilh, a rebeldia de Antígona é uma forma de resistir ao nazismo que exigia tal

${ }^{1}$ GuYomard. O gozo do trágico, p.23. 
disposição de morte daqueles que optavam por opor-se a ele e, em Gambaro, uma maneira de resistir à ação da ditadura argentina. A protagonista de Gambaro diz no final da peça: "Nací para compartir el amor y no el odio. (Pausa larga) Pero el odio manda. (Furiosa) iEl resto es silencio! (Se da muerte con furia)".?

Em nenhuma das obras analisadas, Antígona cede. Submeter-se à Lei de Creonte seria morrer, e dizer não para satisfazer seu desejo, é viver.

ANTÍGONA (sacude la cabeza) - No quieto comprender. Eso está bien para usted. Yo estoy aquí para otra cosa que comprender. Estoy aquí para decirle que no y para morir. CREÓN - iEs fácil decir que no! ANTÍGONA - No siempre. ${ }^{3}$

Este sentimento e esta força são os que nutriram a ação das resistências nas diferentes épocas e espaços. Lacan diz: "Antígona perpetua, eterniza, imortaliza essa Até."4

Antígona está marcada por uma história trágica ${ }^{5}$ que chega ao seu clímax com a morte dos dois irmãos num combate pela posse da cidade de Tebas. Creonte, designado como soberano depois do fatal acontecimento, decidiu prestar honras fúnebres a um deles (Eteocles), por ser quem defende a cidade, e castigar outro (Polinices) à intempérie, por ser quem ataca a polis. Esta decisão é tomada sem contemplar o fato de que o primeiro não respeitou a sucessão do trono e que, finalmente, a morte de ambos se produz pelo desejo avassalador de poder que os mobiliza. Antígona não acata a decisão de Creonte e resolve enterrar seu irmão, estabelecendo assim sua própria morte.

Recordemos que os ritos funerários têm um caráter central dentro das tragédias, visto que são um mandado divino ao qual não se pode apelar. Lacan afirma que o lugar dos heróis de Sófocles é entre os mortos: "são personagens situados de saída numa zona limite entre a vida e a morte". ${ }^{6}$

Antígona, ao não ceder diante da realização de seu desejo, gera uma interrogante sobre o caráter do mesmo: ético? - por opor-se aos deveres político-familiares, de genealogia e religiosos aos do Estado-Cidade representados na Lei de Creonte, deixando sua própria vida em risco ${ }^{7}$ - ou incestuoso? - porque seu gesto final a une indissoluvelmente a Polinices e ao resto de sua família, incluindo seu pai (recordemos que ela é quem o acompanha quando está cego). Guyomard diz: "a questão de Antígona é que essa unicidade inclui o incesto. Um incesto que a fez nascer - sem metáfora e que a faz morrer". 8

Recordemos que de seu núcleo familiar básico em vida só resta sua irmã Ismênia, a quem ela rejeita na obra de Sófocles por ser incapaz de se opor a Creonte na ação e

\footnotetext{
${ }^{2}$ Gambaro. Teatro completo. Antígona furiosa, p.217.

${ }^{3}$ ANOUilh. Antígona, p.97.

${ }^{4}$ LaCan. O seminário. Livro 7, p.342.

${ }^{5}$ Seus pais foram castigados com a morte por cometer incesto, sendo ela um dos filhos nascidos dessa uniāo. Seu pai (Édipo), quem matou seu progenitor sem saber e casou-se com sua mãe (Jocasta), do mesmo modo, cega-se, estabelecendo um parâmetro simbólico entre a cegueira mental na qual viveu, e a física.

${ }^{6}$ LACAN. O seminário. Livro 7, p.330.

${ }^{7}$ Parece-me importante esclarecer que a estruturação da familia é também um fato político que interfere na constituição do Estado e que a forma que assume a cidade determina as relações familiares que no seu interior se estabelecem.

${ }^{8}$ GuYomard. O gozo do trágico, p.32.
} 
pretender fazê-lo somente com palavras e a quem, na obra de Gambaro, protege como se fosse mais fraca que ela: "quiero que escapés a la muerte que a mi me espera". Em relação à problemática do incesto, Levi-Straus afirma:

A proibição do incesto é o processo pelo qual a "natureza se ultrapassa a si mesma". Acende a faísca sob a ação da qual se forma uma "estrutura de novo tipo", mais complexa e "se superpôe, integrando-as", às estruturas mais simples da vida psíquica, assim como estas se "superpõem, integrando-as", às estruturas mais simples que elas próprias, da vida animal. Realiza e constitui por si mesma, o advento de uma "nova ordem". ${ }^{10}$

Na obra de Gambaro, a protagonista expōe abertamente a questão do incesto; na de Sófocles, refere-se implicitamente a ele quando relata as maldições de Édipo:

Antígona: Mi madre se acostó con mi padre, que había nacido de su vientre, y así nos engendró. Y en esta cadena de los vivos y los muertos, yo pagaré sus culpas. Y la mía. Ahí está. Polinices, mi hermano más querido. Creonte no quiere para él sepultura, lamentos, llantos. Ignominia solamente. Bocado para las aves de rapiña. ${ }^{11}$

O importante deste aspecto não é o incesto em si mesmo, senão a transgressão dos limites na funçāo do desejo. Lacan analisa este aspecto e propõe que "Antígona é levada por uma paixão" 12 que está acima do dever familiar ou mortuário. Penso que essa paixão, além de se relacionar com a questão do incesto, que já aparece em Sófocles: "Amada yaceré con él, con el amado, después de cumplir con todos los deberes piadosos; porque mayor es el tiempo que debo complacer a los muertos que a los vivos", ${ }^{13}$ conectase com a questão existencial que a protagonista não se conforma com momentos de felicidade como seria o seu casamento com Hemón. Quer tudo, inclusive o que já não está neste mundo. É desta maneira que entendo esse ir "mais além" de tudo. Isto aparece claramente na seguinte fala da obra de Anouilh:

ANTÍGONA (despacio) - ¿Qué será mi felicidad? ¿En qué mujer feliz se convertirá la pequeña Antígona? ¿Qué mezquindades tendrá que hacer día a día, para arrancar con los dientes su pedacito de felicidad? Dígame, ia quién deberá mentir, a quién sonreír, a quién venderse? ¿A quién deberá dejar morir apartando la mirada? ${ }^{14}$

Antígona estabelece uma hierarquia entre o gesto e a palavra, sendo em seu valor o primeiro muito mais importante que a segunda: assim opta por sua própria morte para realizar o ritual que o Hades ou seu próprio desejo necessitam. Sua ação nos recorda a luta das mães e avós da Praça de Maio para encontrar os corpos das vítimas da ditadura argentina. Muitas delas, esquecendo-se de si mesmas, doaram sua vida na busca de um corpo para uma sepultura vazia. No Chile, há um panteão no Cemitério geral esperando pelos corpos das vítimas da ditadura. Por isso, para Antígona não basta expressar o amor com palavras, como o faz Ismênia, mas é fundamental demonstrá-lo no fazer da existência. Inclusive a Antígona de Anouilh busca infrutiferamente a Hemón antes de morrer para consumar sexualmente sua relação.

\footnotetext{
${ }^{9}$ Gambaro. Teatro completo. Antígona furiosa, p.206.

${ }^{10}$ Strauss citado por Tavares. Troca de mulheres em Lévi-Strauss e Lacan, p.31.

${ }^{11}$ Gambaro. Teatro completo. Antígona furiosa, p.204.

${ }^{12}$ LACAN. O seminátio. Livro 7, p.308.

${ }^{13}$ Sófocles. Antígona, p. 40.

${ }^{14}$ ANoull. Antígona, p.101.
} 
Desta forma, observamos que Antígona "encarna incontestavelmente, a afirmação pura. Afirmação de uma liberdade que não reconhece para si outro limite e outro mestre senão a morte". ${ }^{15}$ Esta tese permite entender porque Anouilh a escolhe como protagonista do seu texto. É uma personagem existencialista que exerce sua liberdade escolhendo a morte em vez de viver uma vida de concessões. Antígona é capaz de gerar sua própria morte para conseguir seu desejo, como diz Di Pina Là Villa, numa relação de igualdade com o outro em oposição às verticais que estabeleceu Édipo. ${ }^{16}$

A problemática do gênero aparece nas três peças e, em todas, Antígona se assume e assume seu desejo diante de um meio que a reprime, que a tacha de louca ou que a silencia:

\section{Sófocles}

Ismena: ... Pues preciso es pensar ante todo que somos mujeres, para no querer luchar contra los hombres. ${ }^{17}$

\section{Anouilh}

Ismena (se lanza hacia ella) - iAntígona! iTe lo suplico! Esta bien para los hombres creer en las ideas y morir por ellas. Pero tú eres una mujer. ${ }^{18}$

Gambaro

Antinoo: iLas mujeres no luchan contra los hombres!

Antígona: Porque soy mujer, nací, para compartir el amor y no el odio. ${ }^{19}$

É muito interessante observar que, durante o transcurso das obras, as personagens estão recriando o mesmo mito, que é contextualizado de diferentes modos. $\mathrm{Na}$ obra de Griselda Gambaro, a última fala, a palavra final, está nas mãos de uma mulher, Antígona. Na de Sófocles e na de Anouilh, o coro é quem entrega a última sentença. Na primeira, para aconselhar prudência e na segunda, para mostrar que toda tragédia existencial, é, finalmente, uma questão puramente individual. Na peça de Anouilh este ato enunciativo tem seu paralelo na ação dos guardas que continuam jogando as cartas sem se importarem com o ocorrido.

Este aspecto nos leva ao caráter de cada uma destas peças. Isto me parece fundamental na medida em que este aspecto reflete a modificação existente no desejo da protagonista, que é nosso tema. Na obra de Sófocles, a tragédia se estrutura em função de mostrar que a ruptura de todos os limites será sancionada, objetivo das tragédias gregas. Por isso, Antígona, que não obedece à lei de Creonte, morre se condoendo de sua situação e Creonte é castigado, pois não segue os preceitos do Hades. Na peça de Anouilh, desde o começo, revela-se que isto é teatro e, portanto, alivia-se a obra da pesada carga que impõe a tragédia de Sófocles. A última fala da peça mostra Antígona escrevendo a Hemón uma carta na qual the pede perdăo, dizendo-lhe que todos ficariam mais tranquiilos sem ela e o coro, na fala final, retoma este ato enunciativo para dizer que tudo terminou e que, mortos aqueles que teriam que morrer, volta-se à tranqüilidade. Nada, nem ninguém, vale tanto como para pro-

\footnotetext{
${ }^{15}$ GuYOMARD. O gozo do trágico, p. 100.

${ }^{16}$ LA VILLA. Internet file: http: www.ser.it.girodivite/cultura/tragedie. htm

${ }^{17}$ SÓFOCLES. Antígona, p.40-46.

${ }^{18}$ AnOUILH. Antígona,p.77.

${ }^{19}$ Gambaro. Teatro completo. Antígona furiosa, p.204.
} 
vocar uma comoção real. Gambaro, por sua vez, mostra uma Antígona orgulhosa de ir em direção à morte, pois é sua forma de se opor a um mundo no qual prima o ódio e não o amor para o qual ela nasceu. Esta personagem estabelece assim um paralelo de sua ação com a de Cristo, pois morre para mostrar a vigência do amor. Esta relação se marca inclusive com signos como o sudário que representa Polinices. Nesta peça, remexe-se a estrutura da tragédia através de uma ruptura da ordem cronológica. A peça inicia com a imagem de Antígona enforcada e termina com ela se matando. $\mathrm{O}$ que gera um tempo circular, sem saída, como a clausura que geram as ditaduras, representadas na carcaça de Creonte.

Depois desta análise estrutural, podemos perceber a diferença entre o desejo da protagonista de Sófocles, que podemos "justificar", baseando-nos no respeito aos deveres da consciência para com os mortos e a família, e o da Antígona de Anouilh, que se "racionaliza" através do exercício de liberdade; da opção pela morte frente ao pragmatismo defendido por Creonte para sobreviver neste mundo absurdo, e com o da protagonista de Gambaro, que se constitui como expressão de confronto genérico proposto pela peça. A Antígona de Gambaro caminha sem vacilar, sem temor e com orgulho até a morte, pois está levantando a bandeira do amor perante ao ódio, mesmo quando seja este o que prime.

Contudo, temos que reconhecer que em todas as Antígonas o motor de sua ação é sempre o desejo, como o foi o do seu pai, Édipo:

(...) a problemática de Édipo gira em torno do desejo de saber e termina com o cegamento de um herói que não soube decifrar esse primeiro e último enigma, à medida que esse decifrar representaria estar Édipo cego para o significante e ser cegado por ele. ${ }^{20}$

e da sua mãe, Jocasta, que, segundo Lacan e seus seguidores, é culpada do incesto, pois ela sabia da existência de seu filho. Postulado com o qual não estou de acordo, porque sabemos que ela foi entregue a Édipo, como o maior bem que possuía Tebas, por ter destruído a esfinge. Em minha leitura, portanto, sua ação, em alguma medida, é produto da troca de mulheres: “De fato, já se viu que não se dão coisas ou presentes do mesmo modo que se dão mulheres, porque a mulher é o 'presente supremo' que só pode ser conseguido através de 'dons recíprocos'”. ${ }^{21}$ Digo em alguma medida, pois entendo que Jocasta não é passiva e que diante do fato de ser entregue ao matrimônio a Édipo toma uma decisão que se relaciona com seu direito à felicidade. Isto ela pode fazê-lo, pois as mulheres sempre tiveram formas de escapar à "troca" produzida pelos homens: “Assim, existe algo 'a mais' na mulher que não passa 'no diálogo matrimonial dos homens', ou, com outras palavras, 'a mulher não é toda submetida à lei da troca."'22 Jocasta deseja e assume o seu desejo.

É interessante observar que Jocasta é um modelo para Antígona, até na maneira de morrer. $O$ desejo feminino, à margem das negociações estabelecidas pelo mundo masculino, historicamente tem sido estigma de maldição e o que Antígona esteja disposta a exercê-lo tem uma carga semântica em todas as obras analisadas e mais

\footnotetext{
${ }^{20}$ SOUZA citada por BRANDÃO. O enigma em Édipo Rei e outros ensaios, p.93.

${ }^{21}$ TAVARES. Troca de mulheres em Lévi-Strauss e Lacan, p.77.

${ }^{22}$ IBIDEM. p.64.
} 
ainda na de Griselda Gambaro, em que o realiza sem remorso. Faz-se necessário que nos detenhamos neste ponto para observar que a peça de Griselda Gambaro se enuncia a partir do gênero feminino e que isto está presente em dêiticos como o recém mencionado ${ }^{23} \mathrm{e}$ inclusive na forma de estruturar a peça (tempo e espaço não são definidos claramente). Este aspecto possibilita universalizar a problemática de Antígona às mulheres desde o período clássico até a atualidade.

A arte das mulheres, ao ser consciente de sua capacidade de mudar os imaginários através de intertextualidades e novas formas de criação, produz interdiscursividades desde um novo lugar de enunciação capaz de dialogar transformativamente com a sociedade. Consciência e vontade de mudança é o que observamos na Antígona furiosa de Gambaro. Ela não só não cede às imposiçōes da Lei representada por Creonte, senão que exerce um desejo sem culpa e com orgulho.

Tradução: Marcos Antonio Alexandre

\footnotetext{
${ }^{23}$ Entendemos o gênero como uma construção cultural móvel que varia de acordo com as distintas sociedades e de acordo com as flutuaçōes das culturas que atravessam ditas sociedades.
} 


\section{RESUMEN}

Este trabajo analiza, a partir de los estudios de género, el personaje de Antígona en relación al deseo. Esta investigación está focalizada en tres piezas: Antigona furiosa de Griselda Gambaro, Antígona de Jean Anouilh e Antígona de Sófocles.

\section{REFERENCIAS BIBLIOGRÁFICAS}

Anoullh, Jean. Antígona. Buenos Aires: Losada, 1997.

BhabHA, Homi. O local da cultura. Belo Horizonte: Editora UFMG, 1998.

Dominguez, Nora Y C. Perilli. Fábulas de género. Sexo y escrituras en América Latina. Rosario: Beatriz Viterbo, 1998.

Gambaro, G. Teatro completo. Antígona furiosa. Buenos Aires: La flor, VIII año 1996.

Guerra, Lucía. La mujer fragmentada. Santiago: Cuarto propio, 1995.

Guyomard, Patrick. O gozo do trágico. Antígona, Lacan e o desejo do analista. Rio de Janeiro: Jorge Zahar editor, 1996.

LACAN, Jacques. O seminário. Livro 7. Rio de Janeiro: Jorge Zahar, 1986.

LA VILLA, Di PINA. Hegel, Holderline la tragedia Greca. Internet File: http: www.ser.it.girodivite/ cultura/tragedie.htm

Montecinos, Sonia. Madres y huachos. Santiago: Cuarto propio, 1991.

Richard, Nelly. Masculino/Femenino: Prácticas de la diferencia y Cultura democrática. Santiago:

Francisco Zegers Editor, 1993.

Sarlo, Beatriz. Escenas de la vida posmoderna. Argentina: Ariel, 1994.

Sófocles. Antígona. Santiago: Renacimiento, 1980.

Souza, Eneida Maria de. O enigma em Édipo Rei. In: Brandão, Jacyntho. O enigma em Édipo

Rei e outros ensaios. Belo Horizonte: UFMG/CNPq, 1985.

Tavares, Hugo. Troca de mulheres em Lévi-Strauss e Lacan. Rio de Janeiro: Hólon, s/d. 